\title{
BIOEFFICACY OF SOME PLANTS ETHANOLIC EXTRACTS AGAINST MAIZE WEEVIL (Sitophilus zeamais) INFESTATION OF STORED MAIZE GRAINS
}

\author{
*Negbenebor, H.E., ${ }^{1}$ and Nura, S. ${ }^{2}$ \\ ${ }^{1}$ Department of Computing and Applied Sciences, Baze University, Abuja, Nigeria. \\ ${ }^{2}$ Department of Biology, Ahmadu Bello University, Zaria, Nigeria. \\ *Corresponding author's email address: salisunura40@yahoo.com \\ (Received: $19^{\text {th }}$ October, 2019; Accepted: 31 ${ }^{\text {st }}$ March, 2020)
}

\section{ABSTRACT}

\begin{abstract}
The experiment was conducted to determine the efficacy of three plants ethanolic extracts against maize weevil (Sitophilus zeamais) on stored maize grains (Zea mays). Five different ethanolic concentrations $(0.5 \mathrm{mg} / \mathrm{L}, 1.0$ $\mathrm{mg} / \mathrm{L}, 2.0 \mathrm{mg} / \mathrm{L}, 4.0 \mathrm{mg} / \mathrm{L}$ and $8.0 \mathrm{mg} / \mathrm{L}$ ) were made from the leaves of Hyptis suaveolens, Alstonia boonei and Tephrosia vogelii with $0.0 \mathrm{mg} / \mathrm{L}$ as the control (ethanol) and applied onto the maize grains by dipping. The experiment consists of six treatments (including control) and was laid in completely randomized design (CRD) with three replications. Data were collected for adult mortality, number of eggs, larval development and percentage grain damage. The data were subjected to analysis of variance (ANOVA) at $5 \%$ probability level with Duncan's Multiple Range Test (DMRT) used to separate the means that were significant. The result obtained revealed significant difference $(\mathrm{P} \leqslant 0.05)$ between the concentrations over the control in terms of toxicity, oviposition, induced adult mortality and progeny suppression. However, the extracts from Tephrosia vogelii are the most toxic and produced the best effect with $\mathrm{LC}_{50}$ of $4.85 \mathrm{mg} / \mathrm{L}$ at 24 hours of exposure and $1.94 \mathrm{mg} / \mathrm{L}$ at 48 hours of exposure. Similar result was found in terms of adult mortality and oviposition suppression. The effect of the extracts is concentration-dependent increase with increase in concentration. The percentage decrease in weight due to the weevil's infestation was found to be reduced with increase in concentrations. Thus, $8.0 \mathrm{mg} / \mathrm{L}$ of the ethanolic extracts of Tephrosia vogelii is recommended for biological control of Sitophilus zeamais against stored maize grains.
\end{abstract}

Key Words: Concentrations, Ethanolic Extracts, Maize, Weevil.

\section{INTRODUCTION}

Maize (Zea mays L.) is one of the most important staple food crops in Nigeria and the highest yielding crop in the world (Whitt et al., 2002). It is the second most common cereal food crop after rice. Maize is a very important food crop for human beings and for livestock. It provides energy, vitamins and negligible amount of protein. Output of maize has continued to increase in Nigeria. About 1336 metric tons of maize was produced in Nigeria in 1986; while in 2003 about 7019 metric tons was produced (CBN, 2003). The livestock industry consumes more than half of the total annual maize production (Babatunde and Oyatoye, 2006). However, despite all the high yielding potential of maize and its significance to the diet of poor man and the Nigerian economy, an estimated $50 \%$ grain lost due to improper storage and attack of insects' pests in tropical countries including Nigeria have been reported (Ahmad and Ahmad, 2002). Insects' pests therefore, were the major cause of economic losses in stored maize grains.
The maize weevil, Sitophilus zeamais Motschulsky (Coleoptera: Curculionidae) is a serious pest of stored maize grains in Nigeria. The weevil caused loss in grain weight ranging between $20-30 \%$ on average (Rees, 2004) which may increase to a total of up to $80 \%$ loss for untreated maize grain in traditional facilities depending on the storage period (Boxall, 2002; Tapondju et al., 2002). The need to control maize weevil using synthetic chemicals imparts negative consequences on to the environment and other non-target population including man, besides conferring resistance and other clinical symptoms in man and other animals. These problems led to a search for more effective method of controlling maize weevil that is safer and eco-friendly. One alternative control method is the use of plant extracts (Viegas, 2003; Trevisan et al., 2006), which favors natural enemies, necessary for the biological balance (Gallo et al., 2002).

Hyptis suaveolens, Alstonia boonei and Tephrosia vogelii were selected for this study due to their relative 
abundance within the vicinity of the local communities in Nigeria and were among the plant species reported to have insecticidal properties against insect pests of stored products such as Aphis gossypii, Aulacophora foveicollis, Bactrocera curcubitae, Callosobruchus maculatus, Diabrotica undecimpunctata, Phyllotreta coniferea, Podagrica spp., Sesamia calamistis and Zonocerus variegatus (Adda et al., 2011; Olaniran and Adebayo, 2013; Ileke and Emmanuel, 2018; Emeasor and Ndumele, 2019). This study therefore aimed at testing the bioefficacy of some plants extracts in the control of $S$. zeamais infestation of stored maize grains.

\section{MATERIALS AND METHODS}

\section{Test Plants}

Fresh leaves of Hyptis suaveolens (Lamiaceae), Alstonia boonei (Apocynaceae) and Tephrosia vogelii (Fabaceae) were procured from vendors at Oyingbo market in Lagos and identified in the Herbarium of the Department of Botany, University of Lagos, Nigeria.

\section{Source of Insects}

The larvae and adults of $S$. zeamais were derived from a laboratory mass rearing facility. Insects were supplied with fresh maize seeds and were reared in wood cages according to the technique described by Dabire et al. (2005). Toxicity tests were carried out on 1st, 3rd and 5th instars larvae and adults of $S$. zeamais.

\section{Preparation of Plants Ethanolic Extracts}

The fresh leaves of the three test plants: Hyptis suaveolens, Alstonia boonei and Tephrosia vogelii were air dried at room temperature, pounded to fine powder with pestle and mortar according to the protocols described by Dabire et al. (2008). The ethanolic extracts were prepared by soaking $100 \mathrm{~g}$ of each powder in $150 \mathrm{ml}$ of $95 \%$ ethanol and shaken in orbital shaker at $120 \mathrm{rpm}$. The preparations were left to stand for another 24 hours and then filtered through a $1 \mathrm{~mm}^{2}$ mesh and then Whatman No 1 filter paper. The filtrates were concentrated to dryness at $40{ }^{\circ} \mathrm{C}$ under reduced pressure on a rotary evaporator and were stored in a refrigerator at $-4{ }^{\circ} \mathrm{C}$ until usage for the experiment. Different concentrations of $0.5,1.00$, $2.00,4.00$ and $8.00 \mathrm{mg} / \mathrm{L}$ were prepared from each of the plant extracts.

\section{Disinfestation of Test Maize Seeds}

Maize grains (Zea mays var. TZESR-20) were obtained from Bariga market, Lagos. They were identified at the International Institute of Tropical Agriculture (IITA), Ibadan. All damaged seeds and debris were sorted out from the grains after which disinfestations was carried out in an oven at $50{ }^{\circ} \mathrm{C}$ for six hours to kill all life stages of insects within the grains. The grains were then left for 24 hours to stabilize at ambient conditions.

\section{Culture of Test Insects}

Sitophilus reamais (Motsch) were maintained on disinfested maize grains. Fifty unsexed 7-14 day old adults of $S$. zeamais were introduced into $500 \mathrm{~g}$ of disinfested maize grains (var-TZESR-20) in 1L kilner jars in five replicates in the laboratory. All adult insects were left for seven days to allow for oviposition, after which they were removed. They were then left undisturbed until adults were observed to emerge. At each peak of emergence, the adults were removed and used to set up new cultures. Series of fresh cultures were made from these to ensure regular supply of adult insects of known ages for use in subsequent experiments.

\section{Storage of Maize Grains Treated with Test Plants Ethanolic Extracts}

Five kilograms $(5 \mathrm{~kg})$ of disinfested maize grains were measured into plastic containers. Concentrations of $0.5,1.00,2.00,4.00$ and 8.00 $\mathrm{mg} / \mathrm{kg}$ of the ethanolic extracts of Hyptis suaveolens, Alstonia boonei and Tephrosia vogelii were applied on the grains and manually agitated and left to air dry. The maize grains were afterwards placed into jute bags and replicated three times. The seeds in the control were treated with ethanol. Thirty unsexed insects were released into each bag as well as that of the control. The bags were kept inside drums in the laboratory. Monthly readings were taken for six months in which $100 \mathrm{~g}$ of the treated and untreated maize were taken from each bag and assessed for insect damage according to Odeyemi and Daramola (2000). The mortality of the insects was determined and used to compute mean lethal concentration $\left(\mathrm{LC}_{50}\right)$ values by probit analysis.

\section{Insect Damage in Grains}

Monthly insect damage in each treatment and control was determined from $100 \mathrm{~g}$ batches of grains in each jute bag as described by Odeyemi 
and Daramola (2000):

$$
\begin{aligned}
& \text { Percentage weight loss }= \\
& \left(\underline{W}_{\underline{u}} \frac{\left.x N_{d}\right)-\left(W_{d} \frac{x}{N_{u}} N_{u}\right)}{W_{u}\left(N_{d}+N_{u}\right)} \times 100\right.
\end{aligned}
$$

Where:

$\mathrm{W}_{\mathrm{u}}=$ Weight of undamaged grains

$\mathrm{N}_{\mathrm{u}}=$ Number of undamaged grains

$\mathrm{W}_{\mathrm{d}}=$ Weight of damaged grains

$\mathrm{N}_{\mathrm{d}}=$ Number of damaged grains

\section{Data Analyses}

The data obtained was analyzed using Analysis of Variance (ANOVA) with SPSS (11.0 versions).
Least Significant Difference was used to separate the means that were significant. Probit analysis was used to determine the $\mathrm{LC}_{50}$ values.

\section{RESULTS}

The result of the relative toxicity of the three plant extracts to $S$. zeamais is presented in table 1 . The result showed that the extracts obtained from Tephrosia vogelii are the most toxic and produced the best effect with $\mathrm{LC}_{50}$ of $4.85 \mathrm{mg} / \mathrm{L}$ at 24 hours of exposure and $1.94 \mathrm{mg} / \mathrm{L}$ at 48 hours of exposure. However, the extracts obtained from Alstonia boonei had the least $\mathrm{LC}_{50}$ value $7.79 \mathrm{mg} / \mathrm{L}$

\begin{tabular}{|c|c|c|c|c|c|c|}
\hline $\begin{array}{l}\text { Ethanolic } \\
\text { Extracts }\end{array}$ & $\begin{array}{c}24 \mathrm{hr} \mathrm{LC}{ }_{50} \\
(\mathrm{mg} / \mathrm{L})\end{array}$ & $95 \% \mathrm{CL}$ & TF & $\begin{array}{l}48 \mathrm{hr} \\
\mathrm{LC}_{50}\end{array}$ & $95 \% \mathrm{CL}$ & TF \\
\hline Tephrosia vogelii & 4.85 & - & 1.32 & 1.94 & - & 1.09 \\
\hline Hyptis suaveolens & 5.27 & $3.37-9.61$ & 1.43 & 4.26 & $2.64-9.60$ & 2.39 \\
\hline Alstonia boonei & 7.79 & $4.88-34.44$ & 2.11 & 3.63 & $1.78-9.49$ & 2.03 \\
\hline
\end{tabular}
at 24 hours after exposure.

Table 1: Relative Toxicity of Various Test Plants Ethanolic Extracts on S. zeamais

Key:

$\mathrm{CL}=$ Confidence Limit

Test of significance $=\mathrm{LC}_{50}$ values with no overlap in $95 \%$ confidence limits are significantly different

Toxicity Factor $(\mathrm{TF})=\underline{48 \mathrm{hr} \mathrm{LC}}{ }_{50} \underline{\text { value of the least toxic compound }}$ $48 \mathrm{hr} \mathrm{LC}_{50}$ value of the more toxic compound

The percentage mortality of $S$. zeamais due to exposure to different extracts from the three test plants is shown in table 2. The result indicated that, $8.0 \mathrm{mg} / \mathrm{L}$ of the ethanolic extracts obtained from T. vogelii, $H$. suaveolens and $A$. boone $i$ induced highest percentage mortality of $83.21 \%, 64.89 \%$ and $60.52 \%$ respectively. The percentage

\begin{tabular}{|c|c|c|c|c|c|c|}
\hline $\begin{array}{l}\text { Ethanolic } \\
\text { extract }\end{array}$ & $0.0 \mathrm{mg} / \mathrm{L}$ & $0.5 \mathrm{mg} / \mathrm{L}$ & $1.0 \mathrm{mg} / \mathrm{L}$ & $2.0 \mathrm{mg} / \mathrm{L}$ & $4.0 \mathrm{mg} / \mathrm{L}$ & $8.0 \mathrm{mg} / \mathrm{L}$ \\
\hline Tephrosia vogelii & $0.00^{\mathrm{a}}$ & $42.50^{\mathrm{a}}$ & $62.00^{\mathrm{a}}$ & $69.82^{\mathrm{a}}$ & $75.15^{\mathrm{a}}$ & $83.21^{\mathrm{a}}$ \\
\hline Hyptis suaveolens & $0.00^{\mathrm{a}}$ & $25.00^{\mathrm{b}}$ & $52.00^{\mathrm{b}}$ & $55.71^{\mathrm{b}}$ & $59.74^{\mathrm{b}}$ & $64.89^{\mathrm{b}}$ \\
\hline Alstonia boonei & $0.00^{\mathrm{a}}$ & $21.50^{c}$ & $46.50^{c}$ & $51.33^{c}$ & $54.25^{\mathrm{c}}$ & $60.52^{c}$ \\
\hline
\end{tabular}
mortality increases with increase in concentration.

Table 2: Mortality of S. zeamais Adults during Exposure to Grains Treated with Ethanolic Extracts of Plants

N.B: Mean value(s) bearing the same letter(s) down a column are not significantly different $(\mathrm{P}=0.05)$

Percentage inhibition of oviposition and suppression of progenies development induced by various concentrations of the test plants extracts is presented in table 3 . The result showed that grains treated with different concentrations of the ethanolic extracts contained different number of laid eggs. The number of laid eggs decreases with increase in concentrations. The least number of eggs was laid at $8.0 \mathrm{mg} / \mathrm{L}$ concentration of T. vogelii -treated grains (30 eggs).
There was also varying number of emerged insects among maize grains treated with ethanolic extracts of the test plants at different concentrations. The lowest mean number of progenies that emerged was 6.65 under $8.0 \mathrm{mg} / \mathrm{L}$ concentration of $T$. vogelii. This value represents $22.09 \%$ of the progenies that emerged as adults. Similar result was found among the remaining extracts from the test plants. The least number of eggs laid and the percentage adult emergence were 
found to be under $8.0 \mathrm{mg} / \mathrm{L}$ of the remaining test percentage of adult emergence decrease with plants extracts. The number of eggs laid and the increase in concentrations.

Table 3: Oviposition and Progeny Development of S. zeamais on Maize Grains

\begin{tabular}{|c|c|c|c|c|}
\hline Plant Extract & $\begin{array}{l}\text { Concentration } \\
(\mathrm{mg} / \mathrm{L})\end{array}$ & $\begin{array}{c}\text { Mean number of eggs } \\
\text { laid }( \pm S E)\end{array}$ & $\begin{array}{c}\text { Mean adult emergence } \\
( \pm \mathrm{SE})\end{array}$ & $\begin{array}{c}\text { Mean percent adult } \\
\text { emergence }(\%)\end{array}$ \\
\hline \multirow[t]{5}{*}{ Tephrosia vogelii } & 0.00 & $90.31 \pm 1.64^{\mathrm{a}^{* !}}$ & $79.00 \pm 6.21^{\mathrm{b}}$ & 87.49 \\
\hline & 1.0 & $57.02 \pm 1.36^{\mathrm{b}}$ & $22.31 \pm 2.24^{\mathrm{e}}$ & 39.13 \\
\hline & 2.0 & $50.21 \pm 3.06^{c}$ & $17.00 \pm 1.85^{\mathrm{f}}$ & 33.86 \\
\hline & 4.0 & $45.02 \pm 1.39^{\mathrm{d}}$ & $12.92 \pm 1.12^{\mathrm{g}}$ & 28.69 \\
\hline & 8.0 & $30.11 \pm 1.27^{\mathrm{e}}$ & $6.65 \pm 1.40^{\mathrm{i}}$ & 22.09 \\
\hline \multirow[t]{5}{*}{ Hyptis suaveolens } & 0.00 & $92.52 \pm 1.84^{\mathrm{a}}$ & $78.12 \pm 6.59^{b}$ & 84.44 \\
\hline & 1.0 & $58.28 \pm 3.01^{\mathrm{b}}$ & $40.33 \pm 5.59^{c}$ & 69.20 \\
\hline & 2.0 & $50.12 \pm 3.97^{c}$ & $30.98 \pm 3.59^{\mathrm{d}}$ & 61.81 \\
\hline & 4.0 & $43.29 \pm 4.21 \mathrm{~d}$ & $20.15 \pm 2.02^{\mathrm{e}}$ & 46.55 \\
\hline & 8.0 & $28.11 \pm 1.12^{\mathrm{e}}$ & $7.73 \pm 0.14^{\mathrm{i}}$ & 27.49 \\
\hline \multirow[t]{5}{*}{ Alstonia boonei } & 0.00 & $95.06 \pm 0.78^{\mathrm{a}}$ & $84.15 \pm 4.18^{\mathrm{a}}$ & 88.52 \\
\hline & 1.0 & $68.11 \pm 2.26 \mathrm{ab}$ & $31.35 \pm 1.23^{\mathrm{d}}$ & 46.03 \\
\hline & 2.0 & $57.82 \pm 2.03^{\mathrm{b}}$ & $20.24 \pm 1.79^{\mathrm{e}}$ & 35.01 \\
\hline & 4.0 & $41.96 \pm 2.32^{\mathrm{d}}$ & $13.25 \pm 1.23 \mathrm{~g}$ & 31.58 \\
\hline & 8.0 & $32.33 \pm 2.50^{\mathrm{e}}$ & $9.13 \pm 1.29^{\mathrm{h}}$ & 28.24 \\
\hline
\end{tabular}

Key: $*^{1}$ Means bearing the same superscripts down a column are not significantly different $(\mathbf{P}=0.05)$

The result of protection of maize grains from $S$. zeamais infestation by various concentrations of the leaf ethanolic extracts obtained from T. vogelii is presented in figure 1 . The result indicated significant difference $(\mathrm{P} \leqslant 0.05)$ in the efficacy of the concentrations in protecting the grains against infestation. The result showed that, all the five concentrations of the test plant gave protection for a maximum of two months except $8.0 \mathrm{mg} / \mathrm{L}$ which extended up to 3 months with no infestation recorded. Similarly, the percentage decrease in weight after six months is low among the treated grains. The least value of reduced damage inferred by the pest on to the grains was found among $8.0 \mathrm{mg} / \mathrm{L}$ treated grains. The effect decreases with increase in concentration. 


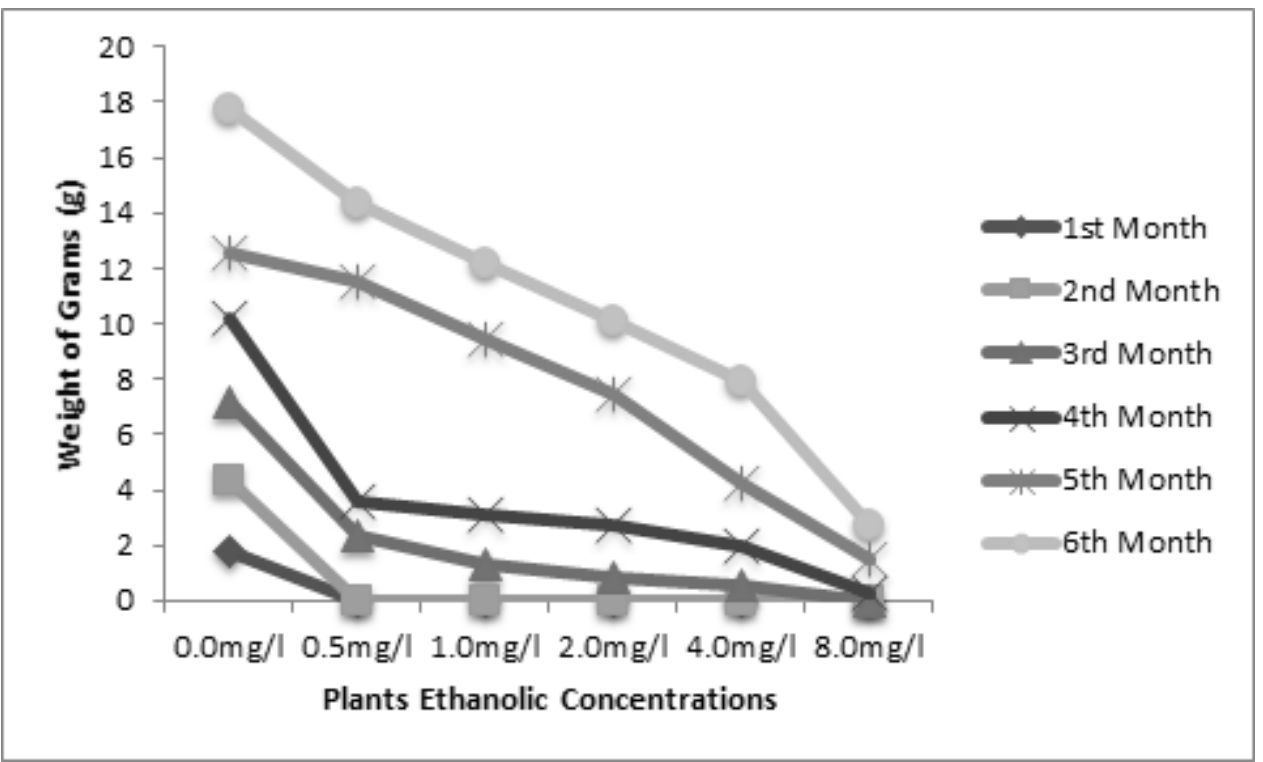

Figure 1: Efficacy of Different Concentrations of T. vogelii in Protecting Stored Maize Grains against $S$. zeamais

The potency of leaf ethanolic extracts from $H$.
suaveolens in protecting maize grains against $S$. zeamais infestation is shown in figure 2 . There was no infestation in the first and second months of treatment except in the control. However, the infestation started at three months and is more severe (except when compared to the control) in $0.5 \mathrm{mg} / \mathrm{L}$ treated seeds in the third and fourth month. Minimum damage was recorded in 8.0 $\mathrm{mg} / \mathrm{L}$ treated seeds within four months. The effect is concentration dependent, decrease with increase in concentration.

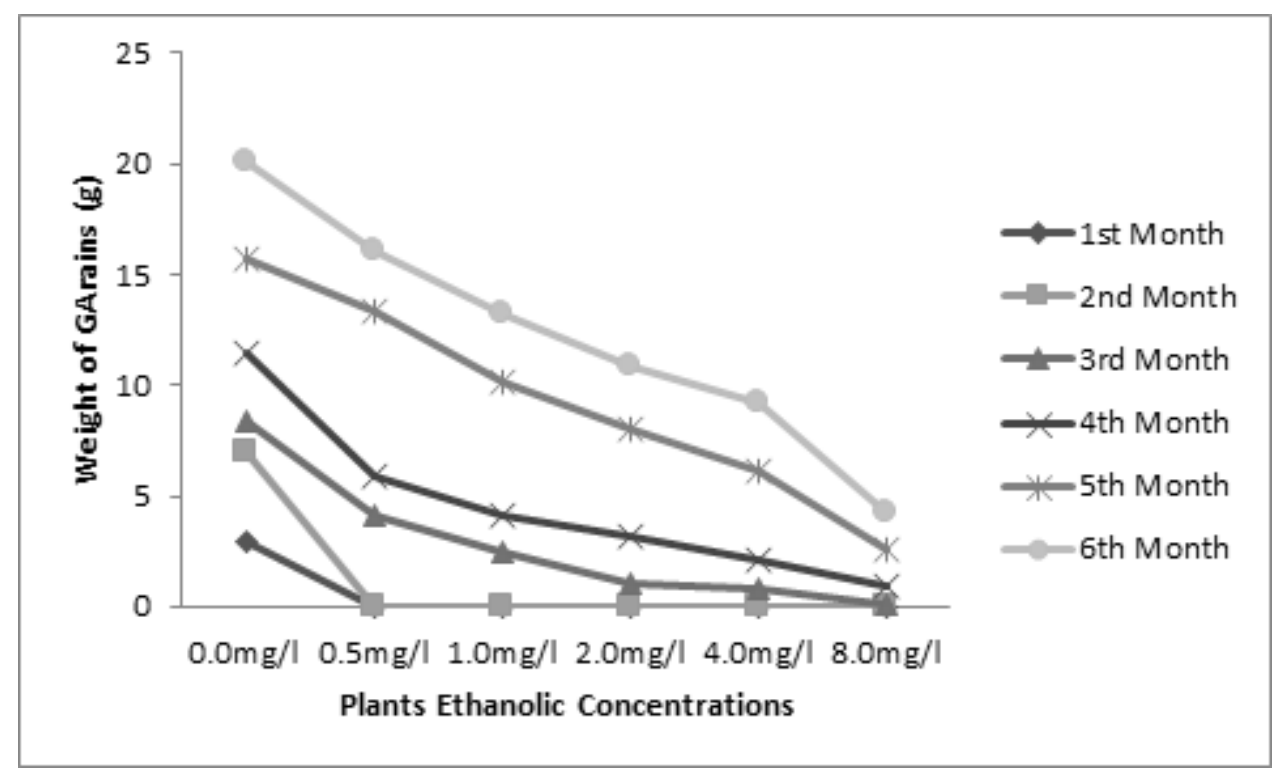

Figure 2: Efficacy of H. suaveolens Concentrations in Protecting Stored Maize Grains against S. zeamais 
The result of the grain protection potency of $A$. boonei leaf ethanolic extracts of maize grains against $S$. zeamais infestation is shown in figure 3 . There was significant difference $(\mathrm{P} \leqslant 0.05)$ in the protection potency of various concentrations of the extracts. Minimum grain damage of $6.21 \mathrm{~g}$ was recorded in maize grains treated with $8.0 \mathrm{mg} / \mathrm{L}$ of A. boonei extract.

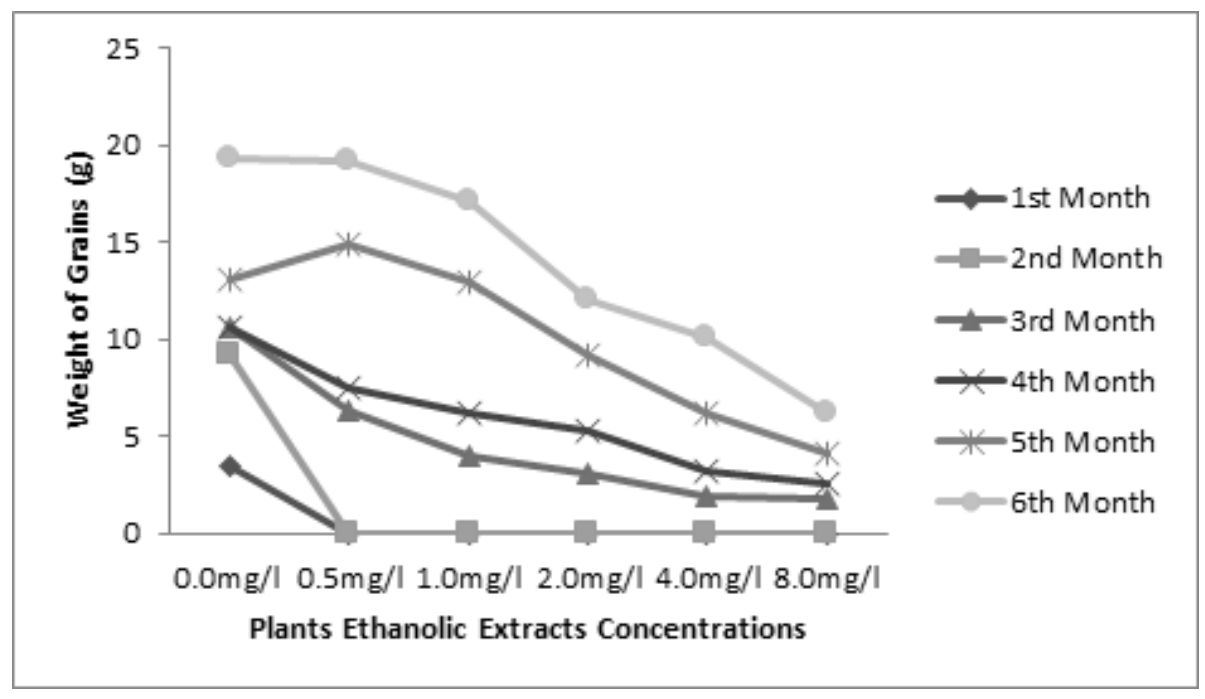

Figure 3: Efficacy of A. boonei Concentrations in Protecting Stored Maize Grains against $S$. zeamais

\section{DISCUSSION}

The high mortality rate of adult $S$. zeamais due to contact with maize grains treated with the three plants extracts: Hyptis suaveolens, Alstonia boonei and Tephrosia vogelii indicated the relative toxicity of the test plants extracts on the weevil. This finding agrees with that of Belmain et al. (2001) who reported that plant extracts have potentials against insect pests' infestation of stored products. Ogendo et al. (2004) reported insecticidal efficacy of T. vogelii on S. oryzae inducing $85-93.7 \%$ insect mortality. Also, Mulungu et al. (2007) reported the efficacy of ethanol extracts of eucalyptus, lantana and neem leaves against $S$. oryzae and $S$. zeamais. The result for the insecticidal efficacy of $A$. boonei on $S$. reamais presented in this study is in agreement with the findings of Ileke and Emmanuel (2018) who reported high bioefficacy of $A$. boonei leaf extract against cowpea beetle (Callosobrochus maculatus) infesting stored cowpea seeds in storage. Similarly, Emeasor and Ndumele (2019) reported the insecticidal potency of aqueous extract of $T$. vogelii in the control of insect pests of cucumber (Cucumis sativus L.), the bioefficacy of Hyptis suaveolens on Anopheles gambiae was reported by Oumarou et al. (2017). However, the finding from this study contradicts that of Ileke (2014) who reported a complete inhibition of adult emergence of $S$. zeamais when exposed to aqueous extracts of $A$. boonei.

The inhibition of adult emergence of the weevils in grains treated with ethanolic leaf extracts of the test plants at different concentrations reported by this study is in agreement with the work of Suleiman et al. (2019) who reported high adult mortalities of maize weevils in the sorghum grains treated with some plants extracts. This induced mortality can probably be attributed to the alteration of physiological processes of the eggs deposited and as such led to inhibition in adult emergence of the weevils in the treated grains. This is in line with the finding of Chudasama et al. (2015) who reported that poisonous substances present in the extracts may enter into the egg through chorion and suppressed further embryonic development. This may probably be attributed to the different active constituents present in these plants as stressed by Kilonzo (1991) and Gerard and Ruf (1995) that plant extracts have a high toxic effect on feeding and survival of different pest species. Similar finding was reported by Onu and Baba (2003), Maina and Lale (2004), Kabeh and Lale (2004) and Mbailao et al. (2006) who individually reported toxicity of plant extracts on Callosobruchus maculatus. 
The effect of the three test plants extracts in suppressing progeny development and oviposition of $S$. reamais can probably be attributed to the ability of the extracts to interfere with the growth and physiological process of developing eggs by reducing food intake thereby reducing assimilation and hence deter growth. This finding is in conformity with that of Osawe $e t$ al. (2007) who reported that the aqueous extracts of $A$. boonei leaves adversely affected the survival and growth of Sesamia calamistis. Similarly, Mukanga et al. (2010) reported suppression of progeny development of larger grain borer (Prostephanus truncatus) by T. vogelli extracts. The growth inhibition may result from toxicity or feeding deterrent properties of the plant as reported by Akhtar and Isman (2004) and Erturk (2006). Iwu and Igboko (1982) established the chemical constituent of Garcinia kola seed as biflavonoids xanthone and benzophenones. $A$. boonei at high concentration also reduced adult emergence of S. zeamais. Suleiman et al. (2018) reported insecticidal efficacy of some plant extracts in suppressing progeny development of $S$. zeamais. The variation in the magnitude of insecticidal efficacy of the three test plants can be due to variations in the nature of active ingredients present in each plant extracts and its effective concentrations. As such, such plants extracts can serve as suitable alternatives for the control of maize weevils.

The protection of the maize grains by the extracts of the three test plants agrees with the work of Appiah et al. (2018) who reported similar finding for the extracts from Hyptis suaveolens and Hyptis spicigera against cowpea weevils. Ileke and Oni (2011) reported $A$. boonei extracts to be highly effective as protectants against $S$. reamais infestation of stored wheat grains.

\section{CONCLUSION}

It was concluded that, ethanolic extracts from the leaves of Hyptis suaveolens, Alstonia boonei and Tephrosia vogelii have high insecticidal activity against $S$. reamais and can protect stored maize grains from its infestation for as long as three months. The effect of the extracts is concentration-dependent, increase with increase in concentration. Thus, $8.0 \mathrm{mg} / \mathrm{L}$ of the ethanolic extracts of Tephrosia vogelii is highly recommended for biological control of Sitophilus zeamais in stored maize grains.

\section{REFERENCES}

Adda, C., Atachi, P., Hell, K. and Tamò, M. (2011). Potential use of the Bushmint, Hyptis suaveolens, for the control of infestation by the pink stalk borer, Sesamia calamistis on maize in southern Benin, West Africa. Journal of Insects Science, 11(33): 1-13.

Ahmad, M. and Ahmad, A. (2002). Storage of food grains. Farm Outlook, 1:16-20.

Akhtar, Y. and Isman, MB. (2004). Comparative growth inhibitory and anti feedant effect of plant extract and pure allelochemical on four phytophagus insect species. Journal of Applied Entomology, 128(1):32-38

Appiah, S.P., Chi, M.V., Adom, D. and Asiedu, F.A. (2018). Pesticidal effects of extracts from Hyptis suaveolens and Hyptis spicigera on cowpea weevils. International Journal of Environment, Agriculture and Biotechnology, 3(5): 1691-1699.

Babatunde, R. and Oyatoye, E. (2006). Food security and marketing problems in Nigeria: the case of maize marketing in Kwara State. http://www.tropentag.de. Retrieved January $4^{\text {th }}, 2019$.

Belmain, S.R., Neal, G.E., Ray, D.E., and Golob, P. (2001). Insecticidal and vertebrate toxicity associated with ethnobotanicals used as post-harvest protectants in Ghana. Food and Chemical Toxicology, 39: 287-291.

Boxall, R.A. (2002). Damage and loss caused by the larger grain borer Prostephanus truncatus. Integrated Pest Management Reviews, 7: 105121.

CBN (2003): Central Bank of Nigeria Statistical Bulletins and Annual Report, 2003.

Chudasama, J.A., Sagarka, N.B. and Sharma, S. (2015). Deterrent effect of plant extracts against Callosobruchus maculatus on stored cowpea in Saurashtra (Guarat, India). Journal of Applied and Natural Science, 7(1):187-191.

Dabire, C., Ba, M.N. and Sanon, A. (2008). Effects of crushed fresh Cleome viscosa L. (Capparaceae) plants on the cowpea storage pest, Callosobruchus maculatus Fab. (Coleoptera: Bruchidae). International Journal of PestManagement, 54:319-326. 
Dabire, C.L.B., Kini, F.B., Ba, M.N., Dabire, R.A. and Foua-Bi, K. (2005). Effet du stade de developpement des gousses de niebe sur la biologie de la punaise suceuse Clavigralla tomentosicollis Stl. (Hemiptera: Coreidae). International Journal of Tropiical Insect Science, 25: 25-31.

Emeasor, K.C. and Ndumele, P.N. (2019). Comparative toxicity of aqueous extract of Tephrosia Vogelii and some synthetic insecticides in the control of insect pests of Cucumber (Cucumis sativus L.). Greener Trends in Plant Pathology and Entomology, $2(1): 1-8$.

Erturk, O. (2006). Antifeedant and toxicity effects of some plants extract on Thaumetopioae solitaria Frey (Lepidoptera: Thaumetopoeidae) Turkish Journal of Biology, 3: 51-57.

Gallo, D., Nakano, O., Silveira Neto, S., Carvalho, R.P.L.; Baptista, G.C. de, Berti Filho, E., Parra, J.R.P., Zucchi, R.A., Alves, S.B. and Vendramin, J.D. (2002). Entomologia Agrícola (Agricultural Entomology). Piracicaba, Fealq, 920 p.

Gerard, P.J. and Ruf, L.D. (1995). Effect of neem, Azadirachta indica extract on survival and feeding of larvae of four keratinophagus insects. Journal of Stored Products Research, 2: 331-350.

Ileke, K. D. and Oni, M.O. (2011). Toxicity of some plant powders to maize weevil, Sitophilus zeamais (motschulsky) [Coleoptera: Curculiondae] on stored wheat grains (Triticum aestivum). African Journal of Agricultural Research, 6(13): 30433048.

Ileke, K.D. (2014). Cheese wood, Astonia boonei De Wild a botanical entomocides for the management of maize weevil, Sitophilus reamais Motschulsky (Coleoptera: Curculionidae). Octa Journal of Biosciences, 2(2):64-68.

Ileke, K.D. and Emmanuel, A.T. (2018). Bioefficacy of Alstonia boonei leaf extract against cowpea beetle Callosobrochus maculatus infesting stored cowpea seeds in storage. Brazilian Journal of Biological Sciences, 5: 673-681.

Iwu, M.M. and Igboko, A.O. (1982). The flavonoids of Garcinia kola. Journal of
Natural Products, 45: 650-651.

Kabeh, J.D. and Lale, N.E.S. (2004). Effects of pre-harvest sprays of Neem (Aqadirachta indica A. Juss) seed products and Pirimiphos-methyl and Harvest Time Modification on infestation of cowpeas by storage bruchids in the field and store in Maiduguri, Nigeria. Nigerian Journal of Entomology, 22: 104-116.

Kilonzo, B.S. (1991). Larvicidal effects of neem, Aradirachta indica on fleas in Tanzania. International Journal of Tropical Insects Science, 12(5\&6): 699-702.

Maina, Y.T. and Lale, N.E.S. (2004). Efficacy of integrating varietal resistance and neem (Aradirachta indica) seed oil for the management of Callosobruchus maculatus infesting

Bambara Groundnut in storage in storage. Nigerian Journal of Entomology, 2: 94-103.

Mbailao, M., Nanadoum, M., Automne, B., Gabra, B. and Emmanuel, A. (2006). Effect of six common seed oils on survival, egg lying and development of the cowpea weevil, Callosobrucbus maculatus. Journal of Biological Sciences, 6(2): 420-25.

Mukanga, M., Deedat, Y. and Mwangala, F.S. (2010). Toxic effects of five plant extracts against the larger grain borer, Prostephanus truncatus. African Journal of Agricultural Research, 5(24): 3369-3378.

Mulungu, L.S., Lupenza, G., Rieuben, S.O.W. and Misangu, R.W. (2007). Evaluation of botanical products as stored grain protectant against maize weevi $S$. zeamais. Journal of Entomology, 4:258-262.

Odeyemi, O.O. and Daramola, A.M. (2000). Storage practices in the tropics: Food storage and pest problems. First Edition, Dave Collims Publication, Nigeria, 2: 235.

Ogendo, J.O., Deng, A.L., Belmain, S.R., Walker, D.J. and Musandu, A.O. (2004). Effect of insecticidal plant materials, Lantana camara L. and Tephrosia vogelii Hook, on the quality parameters of stored maize grains. Journal of Food Technology in Africa, 9: 29-35.

Olaniran, O.A, and Adebayo, T.A. (2013). Control of foliage pests of roselle (Hibiscus sabdariffa L.) using plant extracts of Tephrosia vogelii and Azadirachta indica in 
Ogbomosho, Nigeria. Transnational Journal of Science and Technology, 3(6): 51-62.

Onu, I. and Baba, G.O. (2003). Evaluation of neem products for the control of dermestid beetle on dried fish. Nigerian Journal of Entomological Society, 20: 105-115.

Osawe, N.O., Igho, B.I. and Manuele, T. (2007). Insecticidal activity of the medicinal plant, Alstonia boonei against Sesamia calamistis Hampson. Journal of Zhejiang University B, 8 (10): $752-755$.

Oumarou, M.K., Younoussa, L. and Nukenine, E.N. (2017). Toxic effect of Chenopodium ambrosoides, Hyptis suaveolens and Lippia adoensis leaf methanol extracts and essential oils against fourth instar larvae of Anopheles gambiae (Diptera: Culicidae). International Journal of Mosquito Research, 5(1): 61-66

Rees, D. (2004). Insects of stored products. CSIRO Publishing, Collingwood VIC, Australia

Suleiman, M., Rugumamu, C.P. and Ibrahim, N.D. (2018). Use of botanicals to suppress the development of maize weevil, Sitophilus zeamais Motsch. (Coleoptera: Curculionidae) in stored sorghum grains.
Journal of Agriculture and Veterinary Sciences, 11(2): 01-10.

Suleiman, M., Sani, I., Yusuf, A.M. and Abdullahi, B.K. (2019). Entomocidal activity of some plant extracts against Sitophilus zeamais Motschulsky (Coleoptera: Curculionidae). African Journal of Agricultural Research, 14(34): 1862-1869.

Tapondju, I.A., Alder, A., Fontem, H. and Fontem, D.A. (2002). Efficacy of powder and essential oil from Chenopodium ambrosioides leaves as postharvest grain protectants against six stored products beetles. Journal of Stored Products Research, 38: 395-402.

Trevisan, M.T.S. et al. (2006). Atividades larvicida e anticolinesterásica de plantas do gênero Kalanchoe. Química Nova, 29(3): 415-418.

Viegas, J., C. (2003). Terpenos com atividade inseticida: uma alternativa para o controle químico de insetos. Quimica Nova, 26(3): 390-4003.

Whitt, S.R., L.M. Wilson, M.I. Tenaillon, B.S. Gaut and E.S. Buckler. (2002). Genetic diversity and selection in the maize starch pathway. Proceedings of National Academy of Science, US A, 20:12959-12962. 